\title{
Social Case Work Practices As A Strategy For Patients Welfare In Public Hospitals of Karachi: A Description Of Experience
}

\author{
Sakina Riaz \\ Department of Social Work \\ University of Karachi \\ Naheed Abrar \\ Department of Social Work \\ Federal Urdu University Karachi \\ Saima Akhtar Malick \\ Department of Public Administration \\ University of Karachi
}

\begin{abstract}
This study is divided into five sections and covers a brief overview of the clinical practices of Social Case Work as a strategy for patient's welfare in the Public Hospitals of Karachi. In section one, the concept of Social Case Work in Pakistani pedagogical scenario and Social Case Work's contribution to the current health care system is discussed. The second section of the study covers the review of the literature. The succeeding section, i.e. section III stated the methodology adopted to derive the results of the study. The results of this study, based on the analysis ended by applying the proposed methodology have been argued in section IV. In the concluding section, conclusions and recommendations were presented. In this exploratory research study, the qualitative methods have employed to understand the reasons which are responsible for de-value of Social Case Work Practices in the public hospitals in Karachi.
\end{abstract}

Keywords: Social Case Work, Public Hospital, Social Welfare Officer.

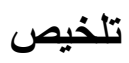

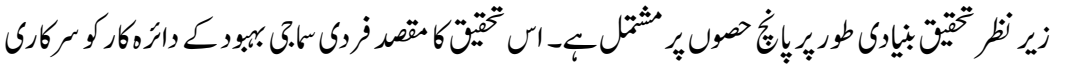

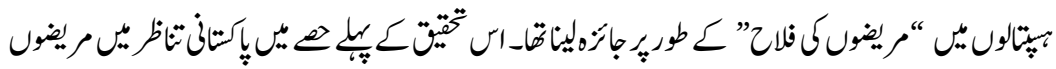
كفالح

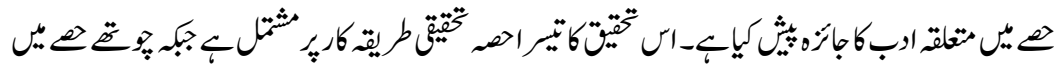

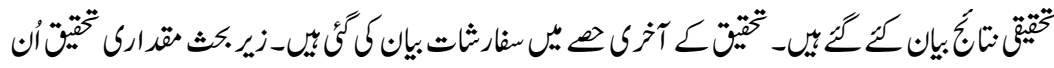




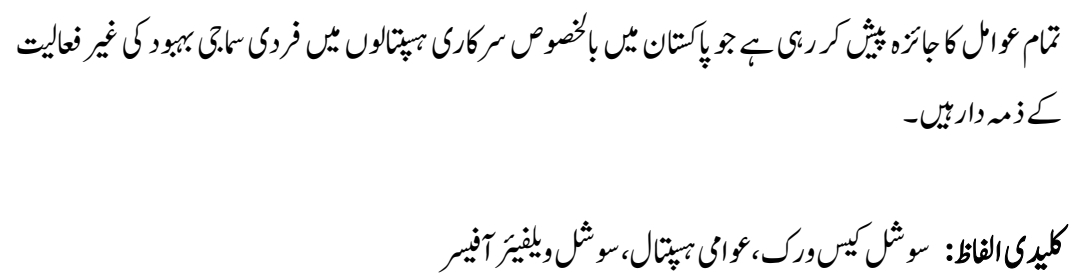

\section{Introduction}

Social Case Work is a professional service which aims to help the individual by providing assistance to Patients, help in their social adjustment problems, and facilitate them in solving their problems. In all Hospitals, it is the prime obligation of the doctor to provide treatment to the patients but in a number of conditions even doctors need the help of Social Case Worker for example patients who have no or limited financial resources, patients who have no job or loss of job due to chronic disease, patients who are the victim of domestic violence, patients who are involved in any criminal activity, patients who has a fear of stigma due to any physical or mental disability or mental retired person. In short, in a professional set-up at hospital it is almost not possible for a doctor to resolve patient's socioemotional or monetary matters.

In the global context, numerous Social Case Worker provides services to patients and families within the hospital setting and recognize that illness especially admission in the hospital may have a direct impact on the psychological, social, and emotional well-being of the individual and his/her family at large. More importantly, in the healthcare setting, there are various social problems which are different from patient to patient, needs special attention, require a special person and special programs to handle the various physical, economic, or social disabilities of patients and help them to stand on par with the rest of the community. A Social Case Worker is best fitted among other health personnel to resolve these issues scientifically and professionally.

Social case work is a professional practice that "aims to enhance social functioning by the provision of practical and psychological help to people in need" (King, et al., 2002). It is viewed by many social work scholars that many of the clients' problems are connected in different means to their social, economic, and political status in society (Jones \& Novak, 1993; Kurland \& Salmon, 1992).

It is hard to describes a daily routine of the duties of social case worker in a hospital setting as they differ from day to day, but by bonding the medical and social needs of the clients they help the individual as a whole person. Interestingly, there is a general perception that social case work is a "highly 
stressful occupation as a result of conflicting roles status, functions and contexts". (Dillon, 1990; Gilbar, 1998; Rushton, 1987).

In hospital setting, Social Case Worker, works within multi-disciplinary team and involved all aspect of patient treatment. The focus of attention for a Social Case Worker is "client" and they try their level best to provide services for the welfare of their client. A variety of services range from pre-admission counselling to discharge from hospital, a social case worker is train in handling patient's psychosocio and economical worries and concerns. They facilitate patients by providing counselling, working on patient satisfaction and assist the client with respect, safety and dignity.

There is much awareness about Social Case Work in developed countries as they practiced in health care institutions and rehabilitation centers. However, due to lack of education, people in developing countries accepted little about the reputation of this field.

In Pakistan, approximately $60 \%$ of the population lives below the poverty line (Kakakhel, 2014); only $2.8 \%$ of the GDP is exceedingly inadequate to gratify the health requests of the humongous population. Sindh is the second largest province of Pakistan .There are 16 districts in Sindh, with Karachi and Tharparkar ranking as the least and most deprived districts, respectively.(Qureshi,2001). Welfare and inequality in the health sector may be scrutinized with a number of welfare indicators, e.g., calories and protein intake, life expectancy at birth, infant mortality rates, etc. However, availability of data has limited the choice to only two indicators, viz., the number of hospital beds and number of doctors per million population (Health Profile Sindh, 1999).

\section{Literature Review}

Social Case Work is the oldest method of Social Work practice, was originated solely in the western world. In generally the English poor law was the landmark in the development of Social Work as a distinct field. The professional method of Social Case Work initiated in USA in the second decade of the century. One of the initial structured efforts in USA to help poor was the establishment of "American Charity Organization Society" was created in Buffalo in 1877(Hassan, S. Mahnaz, 2016). The credit goes to Mary Ellen Richmond (1861-1928), who constructed the basics of the systematic procedure of professional social work.

Parmar (2014) recognized that "Social Case Work is a process, which develops a personality through adjustments consciously affected, individual by individual, between men and their social environment with their problems."In an article entitled "A review of Casework Methods" Margaret A.G.Brown viewed as: 


\begin{abstract}
"Social Case Work, is a helping activity which is made up of a very large number of constituent activities ranging from the giving of material assistance, through listening, expressing acceptance and reassurance, suggesting, advising and the setting of limits, to the making of comments that encourage the client to express or suppress his feelings, to examine his situation or to see connections between his present attitudes and behaviour and past experience".
\end{abstract}

The provision of Social Case services is based upon the Case worker's assessment regarding client situation. Rengasamy; S (2011) had mentioned the three roles including behavioural change role; role as a teacher or mentor and the broker or advocate role. The social case work process starts from: intake; social study; diagnoses; treatment; termination and follow-up. There are more than fourteen models in social work practice which also implies in hospital setting. Many of the models were extensively elaborated by Roberts RW, \& Nee (1972) and Turner (2011). The social casework practice generally based on following models which included:

1) Psychosocial model developed by Gordon Hamilton and her associates,

2) Problem solving model, (developed by Helen Perlman at the Chicago school in 1957)

3) Cognitive Behavioural Therapy (CBT) model, (developed in 1960's)

4) Crisis intervention,

5) Family therapeutic model,

6) Task centered model. (developed at the University of Chicago in the 1970's)

7) Liner Model,

8) System analysis,

9) Management Model,

10) Functional Model (Developed at the Pennsylvania School of Social Work in 1930)

Popple and Leighninger (2004) noticed that the social case work profession has full fill the social work target " of helping individuals who are having difficulty meeting individual role expectations" as micro practice.

\title{
Social Case Work Practices in Health Care in Pakistan
}

Social work in health care is a significant field of practice within country. Social Work in Pakistanis blessed in having a strong convention of Professional understanding at government level since its beginning. In 1947, the arrival and adjustment of Mohajreens and their rehabilitation work within new established country, was done upon the funding, donations or aid basis of Philanthropists (Mohammad Khalid, 2011) in an emergency condition and in a very haphazard 
manner. People involved in social service were un-trained, volunteer who performs this task on the humanitarian basis (Riaz, S. \& Sarfaraz, S.F., 2015).

At the initial stage, the profession has commenced its journey through a short time training course by the help of the United Nations and the first medical social work was employed at TB Control and Training Centre in 1953, under the joint support of the Govt. of Pakistan and the United Nation (Rehmatullah, S., 2002).

Presently, Pakistan has two similar health care systems, public and private. The private hospital services set-up is vast and well- equipped to facilitate almost $80 \%$ of the care management of the overall population in the country.

However, all provincial governments have created a department of health of its citizens (Ather et al, 2009). In contrast, due to the high cost of treatment, the access to the large private hospital is a dream of poor people in Pakistan. Although the largest private hospital in Sindh has claimed for providing welfare services for deserving patients but in reality there is no any organization is working for the entire welfare of cash paying, non-affording patients in Private Hospitals. Though some concessions in the name of charity has been granted to the patients who are not in a position to pay the hospital bill. Similarly, the concept for the provision of an appointment of a professional Social Case Worker has not entertained in the country. Hence, public hospital services set-up is the most regular choice by the lower income group. Due to illiteracy, poverty, and lack of guidance, patients are commonly seen in miserable condition in any Public Hospital. The Social Case Worker has to face all these issues single-handedly in public hospital.

In public hospital, service charges are very marginal and generally named as "Parchi fee" charges. Presently, no proper monitoring mechanism is being taken from the government side in the healthcare organizations for services quality audit. Due to the absence of an operational system to scrutinize the cost and the standard of clinical services offered by the Hospitals in accordance with the quality standard. Yet, this whole set up is neglected and resultantly the citizens of Pakistan are deprived for their elementary human right to attain good healthcare (KhurshidKhowaja, 2009).

Mostly, in all public hospitals, a "Patient Welfare Association" is established for providing monetary benefits to the non-affording patients and provide assistance in patient treatment. They support non-affording, needy patients. Generally, the hospital administrator is responsible to work as Chairman and Social Welfare Officers are work as the secretary of this association. 
Mainly PWA catches funding from following three main sources:

- Zakat Department

- Bait-ul-Maal Department

- Non-Governmental Organization's (NGO) donations

The government of Sindh had imposed ban on the fresh appointment of Social Welfare officers for almost fifteen years. Due to non-availability of job, restricted scope of the subject, this field had faced a lots of troubles for the fresh appointment in the field. Yet, in the mid of 2016, the new induction of Social Welfare Officers was done. Under this scenario, patients and stake holders were faced serious challenging. This situation also damage the professional growth of Case Work Practice in the province of Sindh.

This study is an effort to find-out that how the Social Case Worker job is understood in Public Hospitals and put forward the possible suggestion to correct the mal-perception regarding this important professional practices. This research is an important to realize the possible aspects and will try to focus that in what way the Social Case Worker job is seen in hospitals in the existing Pakistani society? and how we can improve it for the general welfare of the people in Pakistan?

\section{Methodology}

The aim of the present study is to investigate the contemporary Social Case Work Practices in the Public Hospital and discover the challenges' which are affecting the professional growth of the subject in Pakistan. However, little data has been available on the topic under study.

This study is restricted only to the public hospitals of the province of Sindh because the vast majority of Social workers are employed in public hospital. Whereas, there is not a single Social Case Worker have been appointed in any private hospital at provincial level. Therefore, to seek the job in Public sector Hospital is the only choice for social workers who are interested in their career as Social Case work practitioner. While in Sindh, Social Case Workers, deputing in different public hospitals are quite small in number. There are only 13 Social Welfare Officers are deputed in different public hospitals in the province.

Thus, under these circumstances, to consult the Social Case worker in Public hospital for data collection is the single option for the researcher.

This research is an exploratory and qualitative in nature. Using purposive sampling method, field observational visits were also used as a strategy; the data was collected from both primary and secondary sources. 
Three major sources were used by the researcher, to derive a sound analysis:

1. The first was a non-exhaustive list of Social Welfare Officers working in Public Hospital. At present, there is only thirteen (13) Social Welfare officers are deputed in Public hospitals in Sindh. The researcher had approached them directly by using a convenience.

2. The second source consisted of a number of Patients who visited and availed the services at Public Hospital. The researcher solicited them to voluntarily participate in this study.

3. The third source based on researcher's personal knowledge and experience, as the primary researcher has ten years working experience in performing job as Social Welfare Officer.

An attempt has been made for in-depth analysis of the various aspects of existing practices; identify the problems and prospects of Social Case Work with reference to Pakistan.

\section{Findings \&Discussions}

Social Case Work is a challenging professional job that requires a lot of knowledge and skills. The Social Case Worker is an important member of the multi-disciplinary team of professionals working in hospital, fulfilling manifold roles for the well-being of patients. A variety of service ranging from the brief history of client , certifying eligibility of services; harmonizing access to services; evaluating needs; finding accessible facilities; working with family; coordination of services; developing a planner individualized service plan; monitoring of services; crisis intervention; authorizing services; and reassessing client need (Blodgett, P.B. 2015). Beside this, continuity of service, rational decision making, timely record-keeping, and monitoring "treatment" (Cohn \& DeGraff, 1982) are also the key responsibilities of a Social Case Worker.

This study takes a preliminary aspect of the existing scenario and collected information from three key stakeholders;

1. Worker (Professional);

2. Client (patient); and

3. Agency (administration).

The researcher describes all important issues in detail in the study.

\section{The Worker Perspective}

To discuss the certain important challenges faced by SWO in the context of Patient Welfare and Case Work Practices in the Public Hospitals of the Province, the researchers asked different questions with respondents. For instance, asked about 
their role \&job responsibilities, the requirement for Social Case Worker in Public Hospitals and the satisfaction about the job status, professional identification and training issues and the financial \&administrative problems faced by Social Case Workers in the Public Hospitals and reported them separately as follow:

\section{Role \& Job Responsibilities of Social Case Worker in Public Hospital}

The researcher investigated the opinion of Social Case Work about how would they like to describe their role as a Social Case Worker for Patients Welfare in Public Hospitals of Karachi.

Sadly, in Pakistan, the job description of Social Case Work is complex and still in the confusing stage. It is the job of a Social Welfare officer to provide necessary information to the patient about available resources, educate them for its utilization and make all possible efforts in managing these resources for their welfare. Though, the job responsibility of Social Case Workers is to facilitate individual and help in dealing different types of socio-economic problems. It is a professional method which requires skills in human relations \& case management. Besides this, their duties also include "counselling, psychotherapy, psychosocial problems, or emotional behaviour and problems (affective-expressive tasks)" (Cowles, L.A. \& Lefcowitz, M.J., 1992).

Unfortunately, in Pakistan, the role of Social Case Worker as a cultural broker or as a counsellor may also be underutilized within the health care setting. Due to misconceptions about this profession, the job of Social Case worker is restricted to provide financial support and distribute the charity in non-affording or deserving patients. Furthermore, the Case Worker has to do varieties of clinical job like help in the quality of life of patients suffering from terminal stages of the disease; help in declining the suicide rates in patients with substance abuse.

(Hamada. $\mathrm{M}$ et al, 2001); provide guidance to patients and their family at both hospital and home.(Dubus.N.,2010); and in facilitating the research work (Shrivastava, P.S.,2013), (Bobhate,P.S.,2013), (Chan,C.L,2013).

\section{Requirement for Social Case Worker in Public Hospitals}

As a matter of fact, there is an acute shortage of social services in hospitals (both public hospital and private hospital) In Karachi, almost every day 2500 to 3000 patients have visited at Jinnah Hospital and half of them needs guidance, counselling services. The present officers are helpless to cater the needs of poor patients due to financial constraints. It was shared by the Social Case Workers working in public hospitals that Patient Welfare support system needs to be designed in accordance with our population dynamics. Keeping in view the existing situation of the country. 


\section{Job Status of Case Worker in a Public Hospital}

It was noticed with great concerns that almost all Social Workers who deputed in Public Hospitals, although have highly motivated towards Patient Welfare in healthcare setting but the matter related to personal job satisfaction level is concerned; it can be said that majority of them were highly de-motivated with working conditions and lack of facilities in public hospitals.

It is observed that in a hospital setting there are a number of organizational barriers creates a lot of hurdles for Social Case Workers to peruse clinical Practice and they have to constrained their responsibilities of providing help for poor patients, arranging post-hospital care, assisting with community referrals, and other case management and discharge planning functions, with slight weight, time, or space for psychological interventions and psychodynamic clinical practice.

Furthermore during the process of data collection, it was highlighted by the participants that they have to bear different political and religious party pressures for handling patient welfare cases and the situation becomes so critical in the cases of domestic violence, rape, etc. This situation is quite familiar with the study of Rabin B, (1998) in which the influence of bureaucratic, professional and clinical barriers existing within the hospital environment was reported. In another study it was pointed out that some social workers may feel reluctant to admit that they are finding it difficult to cope (Gibson, 2014). The study of Wilberforce et al.,(2014) exposed that the combination of high demands in terms of workload and low control in terms of autonomy and authority to make decisions had a particular detrimental impact in terms of stress.

\section{Professional Identification and Supervision}

The Results of the study revealed that the job and career growth as a Case Worker is less understood in Public Hospitals. It is due to the reason that the job environment and working conditions are not conducive.

Refer to the matter pertaining to the qualification of the Social Welfare Officer was concerned, it was noticed that the majority of them was done their Masters in sociology and working as a Social Welfare Officer in Public Hospitals. It was also observed that some of the Social Welfare Officers had an inadequate knowledge regarding the Social Case Work methods for the case assessment. It might be possible that due to their different educational background as those who were having the Master degree in Social Work were very clear about Case Work practice and procedures as compared to others.

The results of the present research is somewhat resemble with the studies of Jo Moriarty et al., (2015) and (Baginsky, 2014b), who had viewed in both piece of 
researches that "the activities that social workers do are strongly influenced by their expectations about their role that predominate in the countries and agencies in which they practice".

\section{Postgraduate Training}

It was witnessed with great concerns by the researcher that majority of Social Welfare Officers working in Public Hospitals had very limited professional knowledge in terms of reference books, policy, and clinical guidance. A Social Case Worker should be skilled enough in Case Work theory\& Practice, especially in counselling services because in the absence of an accurate understanding of the job function and responsibilities of the Social Case Worker are unable to do their job appropriately.

During the discussion with different Social Workers in public hospitals, it was revealed that some of the Social Welfare officer had lack of ability to perform Case Work practices as they clearly stated that they were not aware about the clinical role of Social Worker in the public hospital due to their different professional back ground (i.e. done Master in sociology and appointed as social welfare officer in Public Hospital).

Despondently admit that lack of on-job training and continuing education, including the provision of guest lectures by the eminent local or international field experts for professional grooming of the Case Worker is missing in the field.

Similarly, it was also exposed during the process of data collection, that due to lack of supervision \& clinical monitoring, and absence of clear understanding about the professional job clarity, most of Social Case Worker, did not have apply the Social Casework direct practice methods properly. It is suggested that their revitalize courses may be designed in consultation with university teachers or qualified professionals in order to boost their skills.

Many researchers in the western world suggest that for securing a professional identity, it is necessary to articulate their expertise and practice to the best of their ability (Woodward, 2001) and (Beddoe,2011a) and job clarity in order to meet the client, colleagues and supervisors' expectations (Rabin \& Zelner,1992).

In the present study, it was felt that due to lack of career planning in government level, the career ladder of the social welfare officer is limited to, director level, lack of training opportunities, slow or time scale promotion creates demotivation among Social Welfare officers in the province. 


\section{Direct Services to the Client}

Almost in all public hospitals located in Pakistan and have a patient welfare department for the welfare of needy patients. This department usually provides sometime full financial support to the deserving patients through Social Welfare Officers deputed in hospital. It was observed that mostly patients were highly satisfied with the services provided by SWO as they coordinate well as they are aware about hospital services. Inform to patients about approx. health expenditures, educate them about diseases. They maintain a cordial relationship and repute with patients, enable them to talk freely and share their views about treatment, hospital discomfort etc. Mostly patients who visited in public hospital, belong to lower income groups, un-educated background.

In short, for poor and uneducated Patient, SWO are very helpful and supportive in Pakistan, as they guide patients appropriately and effectively.

\section{Key Services offered by a Case Worker}

\begin{tabular}{|c|c|}
\hline $\begin{array}{l}\text { Accept \& Help the patient without } \\
\text { any discrimination (children, } \\
\text { young, old, and families, disable, } \\
\text { psychiatric, alcoholic, and } \\
\text { criminal). } \\
\text { Maintain one-to-one professional } \\
\text { relationship with the client. } \\
\text { Patient Proper Assessment for } \\
\text { Welfare. } \\
\text { Pre-admission Counselling. } \\
\text { Post-Discharge Counselling. } \\
\text { Guidance provided about Hospital } \\
\text { services } \\
\text { Education \&Guidance provided to } \\
\text { client about disease and provides } \\
\text { referral services (if required). } \\
\text { Respect, protect and maintain } \\
\text { Privacy of the client. } \\
\text { Help in Preventive, curative and } \\
\text { rehabilitative processes for the } \\
\text { client by using professional } \\
\text { techniques. } \\
\text { Liaison with the Community in } \\
\text { order to facilitate and rehabilitate } \\
\text { the client. }\end{array}$ & $\begin{aligned} &> \text { Collect necessary required } \\
& \text { information about the client to } \\
& \text { prepare the case through } \\
& \text { Interview with client \& family. } \\
&>\text { working with family when } \\
& \text { appropriate; } \\
&>\text { Do Social investigation for } \\
& \text { Socio-cultural, economic and } \\
& \text { psychological situation of the } \\
& \text { client on the basis of observation } \\
& \text { and prepare a case assessment } \\
& \text { report. } \\
&>\text { Diagnosis the social problems of } \\
& \text { the client } \\
&>\text { Design the Plan for treatment } \\
&>\text { Liaison and co-ordinate with } \\
& \text { treating Consultant for removal } \\
& \text { of patient's complaints. } \\
&>\text { Implement the social treatment } \\
& \text { plan. } \\
&>\text { Do follow-up and home visits if } \\
& \text { required. } \\
&>\text { Providing help in continuity of } \\
& \text { care. }\end{aligned}$ \\
\hline
\end{tabular}




\section{Client Seen (Patient's Perspective)}

The Social Case Work is one of the oldest method of social work having the Professional intervention techniques for individual's (Dan, M.Z \& Krbac, 2013). The patient is the center of all service provided by Social Welfare officers through an agency setting. The researcher had also conducted interviews with patients, who had availed the services of Social Welfare Officers in public hospitals and asked about their feed back towards them. Overall, patients were satisfied with the services offered by the Social Welfare Officers. For instance, a patient shared that:

"Due to increase in the financial cost of living, for me it is very difficult to treat cancer disease in a private hospital. I visited to patient welfare department of the private hospital for seeking assistance, and after a prolonged procedure of assessment they refused me for financial support".

Excreted from a discussion with a patient, getting treatment from JPMC. Moreover, the role of a Case Worker is misinterpreted by majority of the health service staff and even patients neither adequately understood nor an adequately valued them as Social Case Work and has been regarded as non-professional. This situation is quite similar to a research (Bove \& Pervan, 2013) noted that social work is included in stigmatized occupations might also be more prone to stress. Lack of understanding about the profession sometimes make it difficult for the hospitalized patients to adjust with Case Worker in Public Hospital settings.

\section{Financial \& Administrative Concerns (Agency Setting)}

The Present study evaluates the role of the Social Case Worker as a strategy for Patient Welfare in a Public Hospital setting. Evidently, the present study pointed out important obstacles at agency level that faced by the professionals. Hence, there are a number of barriers in Public Hospitals which includes: lack of financial resources, lack of coordination between patient Primary consultant and Social Case Worker, lack of Office space, insufficient furniture, and a shortage of staff. Concerns related to ineffective policies, limited opportunity for career growth as expressed by Social Welfare Officers during the discussion with the researcher.

The researcher observed that in public hospitals setting, a categorized structure alike to the original medical model is still fixed inside the organizations, positioning physicians as the greatest important person (Zimmerman, J. \& Dabelko, H., 2007).

It was noted with great concerned that in a public hospital, the Social Case Worker has to face so many reservations about professional competencies. Social 
Case Workers are promised to assist their clients without biasness in any dispute. But in real, there are many inter-departmental territorial conflicts and the political systems inside the public hospital lead to create frustration and less interest in doing job among Social Welfare Officers in Pakistan.

In the present research, there are some key concerns and challenges as recognized by the researcher in the observational visits and discussions with the professionals that Social Workers are over-burden due to involvement in unnecessary administrative jobs, they are facing acute shortage of office staff in public hospitals. Due to non-availability of proper office equipment's i.e. computer, file cabinets, record management is suffered most of the time.

It is viewed that Social Workers are not paid any additional allowance or overtime for extra hour duty or additional work like celebrating cultural, religious or National festivals and for the field work visits. Importantly, there is no any provision of official transport service or separate vehicles for field work or patients follow up visits, if required. Furthermore, they have to face severe shortage due to poor financial management and limited monetary resources to meet the needs of the patients. There is no concept of the availability of a proper counselling room for patients in order to maintain their privacy.

The above-mentioned findings discovered that Social Workers performed a range of tasks and actively involved in handling patients in a Public Hospital, handled their administrative complains, particularly the most shared anxieties of patients were pre or post-discharge problems. These findings also demonstrated the complexity of this role in meeting the needs of patients. These results are quite similar to a research conducted by (NASW, 2006) which reported the "severity of client's problems, caseload size, paperwork and waiting lists for services".

Moreover, the profession takes on the challenge of working across languages, cultures, and values in developing their vision for a more socially inclusive world. In a research, Noordegraaf (2006) found the loss of autonomy among social work and proposed the notion of a hybrid, a crossover to 'the dark side' from a profession. Gilbert and Powell (2010, p.9) argue that critics of the classical approach to understanding professions and noted that it is the extent which professions have always tended to readily adapt to the forces of change, as well as conform to externally dictate organizational policy and procedures'. Social Case workers have to develop their professional skills in collaborative alignment and integrated efforts are required (Shah, N.A., 2015) in order to enhance the status of the healthcare team.

The study exposed that due to the shortage of office space they faced a lot of problems in patient's proper counselling, dignity and privacy. Client's confidentiality 
is being suffered due to a shortage of space. Moreover, weak communication between doctors and Social Case Workers, insufficient provision of facilities for Social Case Workers in Public Hospital were the most important problems.(Carpenter \& colleagues;2015) studied high role conflict, and low job satisfaction was all statistically associated with stress and this is also proved in the present study.

\section{Recommendations}

In the consideration of the above -noted results, this study suggested that various steps should be taken by the government to help and equip them psychologically to undertake their task involved in their role. The research suggested the following recommendations:

- In Pakistan, moving the Social Work profession into the health care organizations requires enormous struggle. This study strongly recommends for appointing Professional Social Case Workers in all hospitals. In order to meet the challenging demands and intricacy of the psychosocial needs of patients, it is important to appoint a professional worker who performs preventive, curative and rehabilitative tasks of patient welfare by using the appropriate theoretical academic knowledge of the field.

- It is suggested that the job description of Social Case Workers should be improved or re-defined according to their knowledge and skills. The Policy makers, Federal and Provisional authorities, Social Welfare Training Institutes, Departments of Social Work at Universities and Public Hospital Authorities and Health Professional may be aligned to improve the existing situation.

- Periodic, specialized training courses should be planned for better training of Social Case Worker and qualified workers, may award through professional license for practices in clinical settings. This step may lead to better quality of professional performance in hospitals.

- More importantly, Social Case Worker must enhance their professional competence in lieu with modern social work approaches and may also conduct appropriate psychosocial interventions, such as play or art therapy with patients and not only limited to stereotype roles for the welfare of patients in our society.

- Furthermore, this study recommends that the Government of Pakistan and the Provincial Government of Sindh should employ Social Case Workers, both, in Public and Private Hospitals settings in accordance with the population.

- Indeed, Social Case worker cannot work in isolation. It is suggested that Social Case Worker should work to improve the communication with Hospital authorities, philanthropists and involve the community 
more dynamically for support and improvement in existing Patient Welfare procedure. It is also recommended that a future study may also be planned to study and compare the role of Social Case Worker in Public and Private Hospitals.

\section{Conclusions}

To conclude, the overall job performance and the quality of Social Case Worker, employed in public hospitals in Karachi City is up to some extent is satisfactory but there is a room for upgrading in approaching towards professional services standard. The Government may recognize that they are professional and not simply the charity distributors. More rigorous and critical scrutiny is required for Case work supervision. Social Case workers needs to be equipped with skills in developing resources, managing teams and access to too much information.

This study finds out that a challenging aspect of this profession concerns with the attitude and practice of social case worker within public hospital. No doubt, Social Case Worker offer a unique and valuable contribution in providing appropriate services in the light of the compound psychosocial needs of patients, their family in hospitals. This study confirms that the social case workers are providing the best possible services in public sector in a very challenging environment with limited resources. Though in Pakistan, Social Case Worker have offering their socio-culturally animated practices with religious zeal and norms and helps the vulnerable patients from last seven decades. A professional approach and commitment is required to bridge the gap between patient focused individualized case work theory and existing public hospital services mechanism. Hence, for optimizing patient welfare services, the Government should take the responsibility to initiate Case Work practice in private hospital setting. This will surely developed new arena of professional growth of patient welfare and case management services in the country.

\section{References}

Ather, H. Akbari, Wimal, Rankaduwa \& Adiqa K. Kiani (2009). Demand for Public Health Care in Pakistan, The Pakistan Development Review, vol.48:2, pp.141-153.

Baginsky, M. (2014b). Social Work: Training for the Profession or Task? Winston Churchill Travelling Research Fellowship. London, Winston Churchill Trust.

Beddoe, L. (2011a). Health Social Work: Professional Identity and Knowledge. Qualitative Social Work. Doe: 10.1177/1473325011415455 
Blodgett, P.B, (2015). Case Management: Challenges for the Rural Panhandle of Texas, Journal of Sociology and Social Work, vol.3:1, pp.76-82.

Bove, L. L. \& Pervan, S. J. (2013). Stigmatized Labour: An Overlooked Service Worker's Stress. Australasian Marketing Journal (AMJ), vol.21:4, pp.259-263.

Bobhate PS, Shrivastava SR. (2013). A Cross-Sectional Study of Knowledge and Practices about Reproductive Health among Female Adolescents in an Urban slum of Mumbai. International Journal of Public Health Research, vol.13:3, pp.307-311.

Carpenter, J., Shardlow, S. M., Patsios, D. \& Wood, M. (2015). Developing the Confidence and Competence of Newly Qualified Child and Family Social Workers in England: outcomes of a national programme. British Journal of Social Work, vol.45:1, pp.153-176.

Chan CL, Suen M. (2013). Validation of the Chinese Version of the Modified Caregivers Strain Index among Hong Kong Caregivers: An Initiative of Medical Social Workers. Health Social Work, vol.38, pp.214-21.

Cohn A. \& DeGraff (1982). Assessing Case Management in the Child Abuse Field. Journal of Social Service Research, vol.5, pp.29-23.

Cowles, L.A. \& Lefcowitz, M.J. (1992). Interdisciplinary Expectations of Medical Social Worker in the Hospital Setting. Health and Social Work, vol.17, pp.58-65.

Dan, M.Z. \& Krbac (2013). The Historical Development of Social Work Practice with Individual, Middle-East Journal of Scientific Research, vol.14:5, pp.703-711.

Dubus N. (2010). Who Cares for the Caregivers? Why Medical Social Workers Belong on End-of-Life Care Teams. Social Work Health Care, vol.49, pp.603-17.

Dillon, C. (1990). Managing Stress in Health Social Work Roles Today. Social Work in Health Care, vol.14, pp.91-108.

Gibson, M. (2014). Social worker shame: a scoping review. British Journal of Social Work, available at http://dx.doi.org/10.1093/bjsw/bcu140, accessed 8 January 2016. 
Gilbert, T. \& Powell, J. L. (2010). Power and Social Work in the United Kingdom: A Foucauldian Excursion. Journal of Social Work, vol.10:1, pp.3-22.

Gilbar, O. (1998). Relationship between Burnout and Sense of Coherence in Health Social Workers. Social Work in Health Care, vol.26, pp.39-49.

Government of Pakistan (2009). PSLM- 2004-05, 2007-08 -Pakistan Social and Living Standards Management Survey. Islamabad: Federal Bureau of Statistics.

Government of Pakistan, (2002). Ministry of Finance. Budget 2001-2002. Pakistan: Finance Division.

Hamada M, Miyata M, Uegaki F., Yamashita T., Yagi M, Iwano A, et al. (2001). The Medical Team Approach to the Suicide- Attempted Patients by Taking Drugsor Chemicals- Participation of the Medical Social Workers. ChudokuKenkyu, vol.14, pp.119-25.

Hassan, S. Mahnaz (2016). Medical Social Work: Connotation, Challenges and Prospects, Pakistan Journal of Social Sciences (PJSS), vol.36:1, pp.495-504.

Health Profile of Sindh (1998-99). Bureau of Statistics, Planning and Development Department, Government of Sindh, Karachi.

Jo Moriarty, Mary Baginsky, Jill Manthorpe (2015). Literature Review of Roles and Issues within the Social Work Profession in England, Kings College London, pp.1-3.

Jones, C. \& Novak, T. (1993). Social Work Today. British Journal of Social Work, vol.23, pp.195-212.

Kakakhel, M. (2014). The Poverty Position in Pakistan. The Nation. Lahore dated 03 October.

Khurshid, Khowaja (2009). International Perspectives: Healthcare Systems and Care Delivery in Pakistan, Journal of Nursing Administration, and, vol.39:6, pp.263-265.

King, R., Lloyd, C. \& Chenoweth, L. (2002). Social Work, Stress and burnout: A Review. Journal of Mental Health, vol.11:3, pp.255-265. 
Kurland, R. \& Salmon, R. (1992). When Problems Seem Overwhelming: Emphases in Teaching, Supervision, and Consultation. Social Work, vol.37, pp.240- 244.

Mohammad, Khalid (2011). Social Work Theory and Practice: With Special Reference to Pakistan, $7^{\text {th }}$ Edition, Kifayat Academy, pp.34-36.

Miller, J. (2006). Skills, Bravery, Courage and Foolhardiness: Seventy-Five Years of Social Work in Health Care in Melbourne. Australia Social Work in Health Care, vol.43:2-3, pp.173-191.

National Association of Social Workers (2006) Assuring the Sufficiency of a Frontline. Workforce: A National Study of. Licensed Social Workers. Accessed on $16^{\text {th }}$ Jan, 2017. http://workforce.socialworkers.org/studies/ nasw_06_exesummary.pdf

Noordegraaf, M. (2006). Professional Management of Professionals. Hybrid Organizations and Professional Managers in Care and Welfare. In J. W. Duyvendak, T. Knijn\& M. Kremer (Eds.), Policy, People, and the New Professional: De-Professionalization and Re-Professionalization in Care and Welfare Amsterdam: Amsterdam University Press, pp.181-193.

Parmer, A. (2014). Methods of Social Work and Its Role in Understanding the Team Climate and Team Effectiveness for Organizational Development. Journal of Sociology and Social Work, vol.2:1, pp.303-318.

Poullier JP, Hernandez P, Kawabata K, Savedoff WD. (2003). Patterns of Global Health Expenditures: Results for 191 Countries. In: Murray CJL, Evans DB, eds. Health Systems Performance Assessment: Debates, Methods and Empiricism. Geneva, Switzerland: World Health Organization. P.51.

Popple, P. R. \& Leighninger, L. (2004) Social Work, Social Welfare and American Society. Allyn\& Bacon.

Rabin B, Lehmann S, Kedar D, Hegar A, Dori N. (1998). An Off-Site Orientation Program for Medical Social Workers. Soc Work Health Care, vol.27, pp.43-55.

RabinC \& Zelner, (1992). The Role of Assertiveness in Clarifying Roles and Strengthening Job Satisfaction of Social Workers Multidisciplinary Mental Health Settings. British Journal of Social Work, vol.22, pp.17-32. 
Rehmatullah, Sherin (2002). Social Welfare in Pakistan. Oxford University Press, Karachi, pp.303-314.

Rengasamy, S. (2011). Social Casework, Madurai Institute of Social Sciences, India, p.29.

Riaz, S. \& Sarfaraz, S.F. (2015). Need and Importance of Medical Social Work Practice in Pakistan with Special Reference to Karachi City. Advances in Social Sciences Research Journal, vol.2:12, 73B80. Accessed on $12^{\text {th }}$ Jan, 2017, http://www.socialserviceworkforce.org/system/files/resource/files/ Medical\%20Social\%20Work\%20Practice\%20in\%20Pakistan.pdf

Qureshi, Moeen (2001). Social Development in Pakistan Annual Review, Social Policy and Development Centre, Karachi. (p:125)Accessed on $12^{\text {th }}$ Jan, 2017, http://www.spdc.org.pk/Project_detail.aspx?sysID=23

Roberts RW, Nee RH. (1972). Theories of social case work. London: University of Chicago Press.

Roberts, R. W. \& Nee, R. H., eds (1970). Theories of Social Casework. Chicago, IL: Chicago University Press.

Rushton, A. (1987). Stress amongst Social Workers. In RPayne \& J. FirthCozens (Eds.), Stress in Health Professionals Chichester: John Wiley \& Sons, pp. 167-188.

Shah, N.A. (2015). Social Work Teaching in Pakistan Problems and Remedies, New Horizons, vol.9, p.103. Accessed on $12^{\text {th }}$ Jan, 2017, http://www.greenwich.pk/PDFs/NH_V09_N1.pdf

Shrivastava PS, Shrivastava SR (2013). Post- Burn Avenues in Rehabilitation of Female Burn victims. Journal of Medical Social Sciences, vol.27, pp.25-30.

Shrivastava SR, Shrivastava PS. (2013). HIV- Tuberculosis Interface: A Comparison of Collateral Prevalence of HIV and Tuberculosis in an Urban Health Center. Ann Trop Med Public Health, vol.6, pp.290-6.

S. Siddiqi, S. Hamid, G. Rafique, S.A. Chaudhry, N. Ali, S. Shahab \& R. Sauerbon (2002). Perception Practices of Public and Private Health Care Providers in Attock District of Pakistan, International Journal of Planning and Management, vol.17, pp.23-40.

Turner, F. J., ed. (1974). Social Work Treatment: Interlocking Theoretical Approaches. New York: The Free Press. 
Turner, F.J. (2011) Social Work Treatment: Interlocking Theoretical Approaches, 5th edn. New York: Oxford University Press.

Whittaker JK, Tracy EM. (1989). Social Treatment: An Introduction to Interpersonal Helping in Social Work Practice. New York: Aldine de Gruyter.

Wilberforce, M., Jacobs, S., Challis, D., Manthorpe, J., Stevens, M., Jasper, R., Fernandez, J.L. Glendinning, C., Jones, K., Knapp, M., Moran, N. \&Netten, A. (2014). Revisiting the Causes of Stress in Social Work: Sources of Job Demands, Control and Support in Personalized Adult Social Care. British Journal of Social Work, vol.44:4, pp.812-830.

Woodward, P. (2001). Mental Health and Social Work. In M. Connolly (Ed.), New Zealand Social Work: Contexts and Practice. Auckland: Oxford University Press, pp.181-192.

Zimmerman, J. \& Dabelko, H. (2007). Collaborative Models of Patient Care: New Opportunities for Hospital Social Workers. Social Work in Health Care, vol.44:4, pp.33-47.

Dr. Sakina Riaz is an Assistant Professor in the Department of Social Work, University of Karachi.

Prof. Dr. Naheed Abrar is Chairperson in the Department of Social Work, Federal Urdu University, Karachi.

Dr. Saima Akhtar Malick is an Assistant Professor in the Department of Public Administration, University of Karachi. 